\title{
ENHANCEMENT OF BIOGAS PRODUCTION BY USING A TWO-STAGE PROCESS FOR THE ANAEROBIC DIGESTION OF CHEESE WHEY
}

\author{
Margarita A. Dareioti ${ }^{1}$ \\ Spyros N. Dokianakis ${ }^{2}$ \\ Constantina Zafiri ${ }^{1}$ \\ Michael Kornaros ${ }^{1 *}$ \\ ${ }^{I}$ Department of Chemical Engineering, University of Patras, \\ Environmental Processes Engineering Laboratory, GR-26500 Patras, Greece \\ ${ }^{2}$ Technological Educational Institute of Crete, School of Agricultural \\ Technology, Stavromenos, GR-71004 Heraklion Crete, Greece \\ *telephone: +30 2610 997418; fax: +30 2610 969556; \\ e-mail: kornaros@chemeng.upatras.gr
}

\begin{abstract}
Cheese making companies have a specific product that is seasonally produced and, like most other agro-industries, generate wastewaters characterized by a high organic loading. Cheese whey is the most important waste stream produced having a high organic content (up to $70 \mathrm{~g}$ $\mathrm{COD} / \mathrm{L})$, which is highly biodegradable, and low alkalinity $(50 \mathrm{meq} / \mathrm{L})$. Cheese production industries worldwide generate more than 145 million tones of liquid whey per year. Because of these characteristics, cheese whey may cause serious environmental problems on the local municipal sewage treatment systems or water receptors if disposed untreated.

Anaerobic digestion is a particularly attractive treatment solution for high strength wastewaters due to the operational economy and generation of biogas and therefore is considered as a promising solution for energy production from cheese whey, in this case.

In this work, a comparative study between single and two-stage anaerobic treatment of cheese whey was conducted in order to enhance biogas production. Our experiments were carried out using one reactor for the single-stage process (operated at a HRT of $20 \mathrm{~d}$ ), and two reactors connected in series, from which the first one was used for acidogenesis (operated at a HRT of $3 \mathrm{~d}$ ) and the other for methanogenesis (operated at a HRT of $20 \mathrm{~d}$ ). The single-stage process presented many operational problems, as a result of little or no buffering capacity of whey, which caused the $\mathrm{pH}$ of the anaerobic digester to drop drastically and the process being inhibited. This kind of inhibition proved to be irreversible and the digester was not able to recover even though it was operated batchwise and the value of the $\mathrm{pH}$ was restored to 7.0. On the contrary, the two-stage process exhibited a stable biogas production rate of 1.57 $\mathrm{L} / \mathrm{L}_{\text {reactor }} / \mathrm{d}$ with the composition of methane in the biogas reaching $54.3 \%$. The dissolved COD and total carbon concentration removal was $70.5 \%$ and $77.2 \%$ respectively.
\end{abstract}

\section{KEYWORDS}

Agroindustrial wastewaters; anaerobic digestion; cheese whey; two-stage process; methane. 


\section{INTRODUCTION}

Some agro-industries such as cheese factories represent a considerable share of the Mediterranean countries economy. Industries processing agricultural products use as raw materials various fruits, vegetables, meat, milk etc. and generate millions of tons of wastewaters and large amounts of by-products, which are totally unexploited and in some cases dangerous for the environment.

Cheese whey $(\mathrm{CW})$, one of the major by-products of the dairy industry, contains a significant amount of carbohydrates (4-5\%), mainly lactose, proteins not exceeding $1 \%$, fats at about $0.4-0.5 \%$, lactic acid less than $1 \%$ and salts that may range from $1 \%$ up to $3 \%$ [1]. It is highly biodegradable with a very high organic content (up to $70 \mathrm{~g} \mathrm{COD} / \mathrm{L}$ ) and low alkalinity (50 $\mathrm{meq} / \mathrm{L})[2]$.

Anaerobic digestion process is a particularly attractive treatment solution for high strength wastewaters due to the operational economy and generation of biogas with pollution decreasing at the same time. In addition, in the specific case of agroindustrial wastewaters treatment the remaining stabilized slurry after digestion may be used as a fertilizer [3]. It is essential to develop sustainable energy supply systems that aim at covering the energy demand from renewable sources. A significant number of biogas plants have been built, mainly in Northern Europe, and now the concept is spreading all over the world. Biogas plants treat various types of organic residues including sewage sludge, food industry residues and manure. Several studies show that, generally, the sensitivity of the AD process may be improved by combining several waste streams.

Anaerobic digestion can be employed as a first biological treatment process necessary for partial stabilization of agricultural and food processing wastes (such as cheese whey). The idea of developing anaerobic digestion as a two-phase process originated from the view that it is generally a process involving two different sets of activities. Overall, the two-phase process takes advantage of the phase separation phenomenon, deriving naturally from different kinetic rates. This provides separate acidogenic and methanogenic reactors to decrease the cost, and to improve treatment efficiency, energy production and process stability of anaerobic systems [4].

Previous studies have been carried out exhibiting cheese processing wastewaters and cheese whey treatment with different types of reactors such as PABR [5], UASB [6, 7], CSTR [8, 9], anaerobic membrane reactor [10] etc.

The aim of this work is to examine and compare, in the lab scale, the performance between a single-stage and a two-stage anaerobic mesophilic process for the treatment of cheese whey operating in similar hydraulic retention times (HRT).

\section{MATERIALS AND METHODS}

The cheese whey was provided from a cheese factory located in the region of Western Greece producing mainly the white cheese "feta" with a daily production of $25 \mathrm{~m}^{3}$ of wastewaters. Cheese whey was collected fresh and stored immediately after sampling in the freezer at $-18^{0} \mathrm{C}$ until subsequent use throughout the experimentation period. The mean composition of cheese whey $(\mathrm{CW})$ is summarized in Table 1. 
Table 1. Composition of cheese whey $(\mathrm{CW})$

\begin{tabular}{lll}
\hline PARAMETER & Unit & $\mathrm{CW}$ \\
\hline $\mathrm{pH}$ & - & 6.07 \\
$\mathrm{TSS}$ & $\mathrm{g} \mathrm{L}^{-1}$ & 9.00 \\
$\mathrm{VSS}$ & $\mathrm{g} \mathrm{L}^{-1}$ & 8.00 \\
$\mathrm{TS}$ & $\mathrm{g} \mathrm{L}^{-1}$ & 56.88 \\
VS & $\mathrm{g} \mathrm{L}^{-1}$ & 33.51 \\
Total COD & $\mathrm{gO}_{2} \mathrm{~L}^{-1}$ & 76.46 \\
Dissolved COD & $\mathrm{gO}_{2} \mathrm{~L}^{-1}$ & 53.46 \\
BOD & $\mathrm{gO}_{2} \mathrm{~L}^{-1}$ & 36.00 \\
Total Carbohydrates & $\mathrm{g} \mathrm{L}^{-1}$ & 54.8 \\
Dissolved Carbohydrates & $\mathrm{g} \mathrm{L}^{-1}$ & 29.2 \\
TKN & $\mathrm{gN} \mathrm{L}^{-1}$ & 0.73 \\
Ammonium Nitrogen & $\mathrm{gN} \mathrm{L}^{-1}$ & 0.10 \\
Total Phosphorus & $\mathrm{gP} \mathrm{L}^{-1}$ & 0.32 \\
Dissolved Phosphorus & $\mathrm{gP} \mathrm{L}^{-1}$ & 0.20 \\
Total Phenols & $\mathrm{g} \mathrm{L}^{-1}$ & 0.09 \\
Alkalinity & $\mathrm{gCaCO}_{3} \mathrm{~L}^{-1}$ & 0.80 \\
\hline
\end{tabular}

For the single-stage process one CSTR reactor was used for the entire anaerobic process $(4 \mathrm{~L}$ working volume), while for the two-stage process experiments two CSTR reactors were utilized, one for acidogenesis $(750 \mathrm{ml}$ working volume) and another one for methanogenesis (4 L working volume). All CSTR reactors were cylindrical in shape, with double walls and made entirely of stainless steel (INOX SS316). The CSTR for the single-stage process was operated at a hydraulic retention time (HRT) of 20 days, whereas the overall HRT for the two-stage process was 23 days ( 3 days for the acidogenic CSTR and 20 days for the methanogenic). Agitation was realized by a geared motor drive unit which was installed on the top of each reactor. The feedstock was stored in a tank placed in a refrigerator to maintain its temperature constant at $4^{0} \mathrm{C}$. All reactors were kept at constant temperature of $35 \pm 0.2^{\circ} \mathrm{C}$ via a thermocouple controller.

For the single-stage process $250 \mathrm{ml}$ of feedstock $(\mathrm{CW})$ were fed daily to the anaerobic reactor via a precise peristaltic pump. For the two-stage process, $250 \mathrm{ml} \mathrm{CW} /$ day were fed to the acidogenic reactor and the effluent from this reactor was used as feed for the methanogenic one. Biogas was measured automatically by a tailor-made device operating via a combination of one engine oil filled U-tube, an electron - valve and a counter. The measurement was based on counting the number of displacements of constant oil volume by the produced biogas. Dissolved and total COD, total and volatile solids (TS, VS), $\mathrm{pH}, \mathrm{TKN}$, ammonium nitrogen, total and ortho - phosphates, alkalinity, carbohydrates, phenolic compounds, volatile fatty acids (VFA) and biogas composition were determined [11,12] throughout the experimentation period in both systems.

For the single-stage process, prior to $100 \%$ feeding with $\mathrm{CW}$, the methanogenic reactor was operated with $100 \%$ liquid cow manure (LCM). Alkalinity in the reactor was kept in satisfactory levels by adding $14 \mathrm{~g} / \mathrm{L} \mathrm{NaHCO}_{3}$ and $0.50 \mathrm{~g} / \mathrm{L}$ of $\mathrm{NH}_{2} \mathrm{CONH}_{2}$ in the feed in order to ensure surplus in nitrogen concentration in the feed of the methanogenic reactor.

For the two-stage process, the acidogenic reactor was filled up with $750 \mathrm{ml}$ of feed, which consisted of $100 \%$ of $\mathrm{CW}$ and was operated anaerobically at a batch mode for $72 \mathrm{~h}$ in order to activate the indigenous microflora and was subsequently switched to continuous mode at the designated HRT (3 days). Prior to cultivation, the reactor was flushed with argon gas for 
10 min to ensure anaerobic conditions. The reactor was operated under these conditions for 69 days.

The methanogenic reactor was seeded in the $6^{\text {th }}$ day with $4 \mathrm{~L}$ effluent from the methanogenic reactor of the single-stage process. Following this step, the effluent of the acidogenic reactor was fed to the methanogenic according to the operating HRT (20 days). $14 \mathrm{~g} / \mathrm{L} \mathrm{NaHCO} 3$ and $0.50 \mathrm{~g} / \mathrm{L}$ of $\mathrm{NH}_{2} \mathrm{CONH}_{2}$ were also added in the feed of the methanogenic reactor to keep the alkalinity and nitrogen concentration in satisfactory levels.

\section{RESULTS AND DISCUSSION}

\subsection{Single-stage process}

As shown in Figure 1 (a) biogas production rate presented a gradual increase until the $34^{\text {th }}$ day of operation reaching $3.59 \mathrm{~L} / \mathrm{L}_{\text {reactor }} / \mathrm{d}$ while, afterwards, the rate decreased to 0.32 $\mathrm{L} / \mathrm{L}_{\text {reactor }} / \mathrm{d}$. Changing the HRT to 30 days, due to the high concentration of VFAs (Figure 2 (b)), resulted in the production of $0.67 \mathrm{~L}$ of biogas $/ \mathrm{L}_{\text {reactor }} / \mathrm{d}$ which was stabilized until the HRT was changed again from 30 to 40 days. Biogas production finally decreased to 0.6 $\mathrm{L} / \mathrm{L}_{\text {reactor }} / \mathrm{d}$. The highest methane production rate was $1.88 \mathrm{~L} \mathrm{CH}_{4} / \mathrm{L}_{\text {reactor }} / \mathrm{d}$ and was observed in the $34^{\text {th }}$ day. However, it was finally stabilized to $0.25 \mathrm{~L} \mathrm{CH}_{4} / \mathrm{L}_{\text {reactor }} / \mathrm{d}$.

A gradual decrease in effluent $\mathrm{pH}$ from 7.8 to 6.95 was observed from the first day until the $82^{\text {th }}$ day of operation (Figure 1 (b)). The total bicarbonate alkalinity after the addition of $\mathrm{NaHCO}_{3}$ ranged to $12420 \mathrm{mg}$ of $\mathrm{CaCO}_{3} / \mathrm{L}$.

During the first 41 days of the experiment there was no production of VFAs. After this day, accumulation of acetic and propionic acid was observed. With increasing HRT in the reactor the value of VFAs concentration decreased but still remained at high levels (see Figure 2 (a) and (b)).

The removal of total carbohydrates was $94.5 \%$ in glucose equivalents (data not shown), since the influent concentration of carbohydrates $(31.6 \mathrm{~g} / \mathrm{L})$ decreased to $1.75 \mathrm{~g} / \mathrm{L}$.

The dissolved COD removal at the steady state was $62.5 \%$ (mean value). The removal of COD in conjunction with gas production in the reactor provided evidence of effective microbial activity from methanogenic bacteria. The TS removal efficiency remained constant, about $30.9 \%$ from 56.88 (influent) to $39.3 \mathrm{~g} / \mathrm{L}$ (effluent). On the other hand, the removal efficiency in VS concentration for the examined scenario was $41.9 \%$ from 33.51 to $19.47 \mathrm{~g} / \mathrm{L}$ (Figure 3(a) and (b)). 

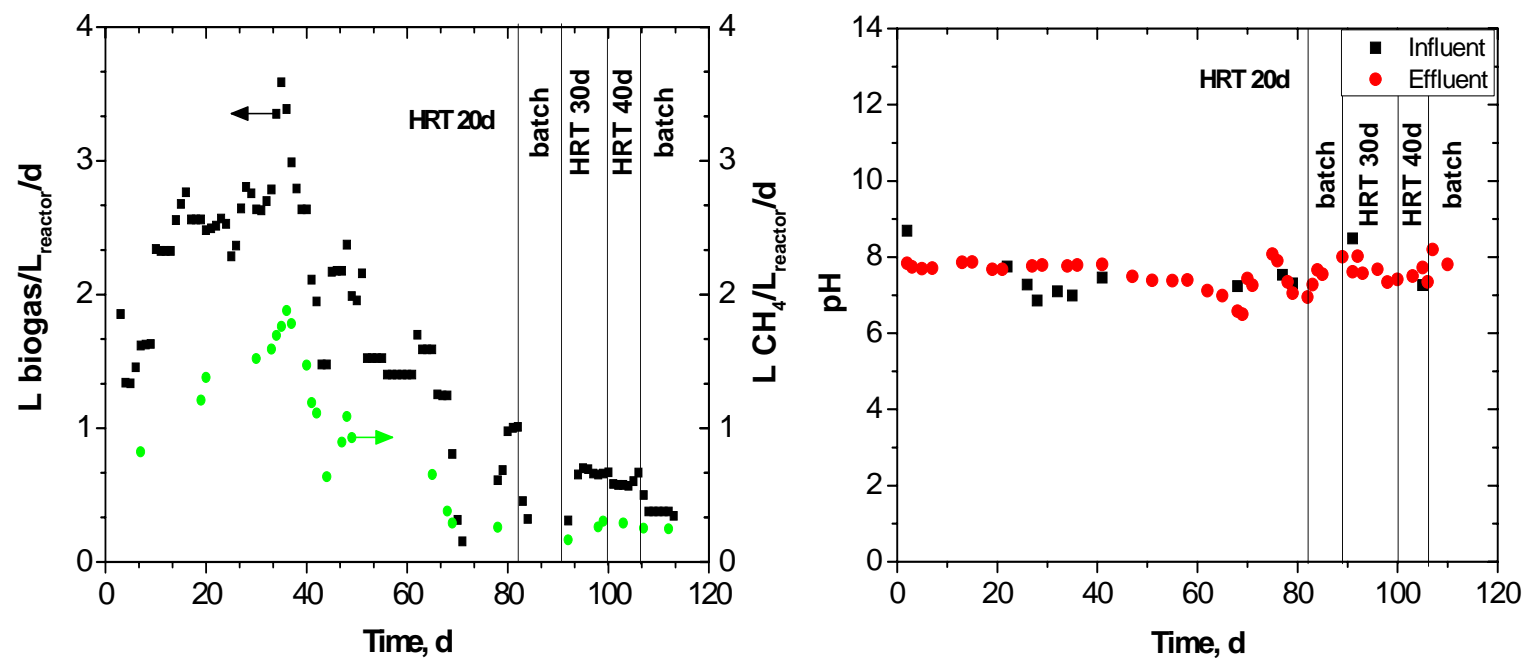

Figure 1. (a) Biogas and methane production and (b) Evolution of pH during the operation of the anaerobic reactor (single-stage process).
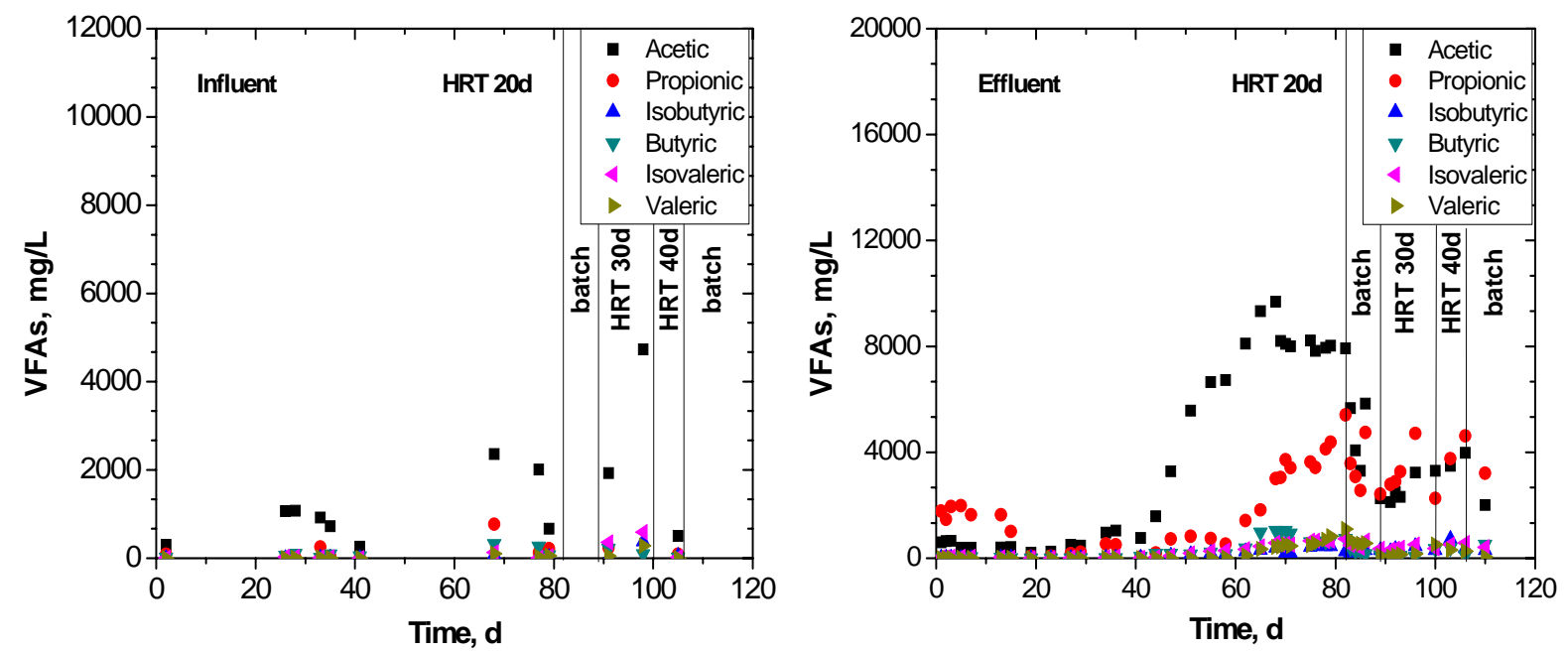

Figure 2. Concentration of Volatile Fatty Acids (VFAs) in (a) the influent and (b) the effluent of the anaerobic reactor (single-stage process). 

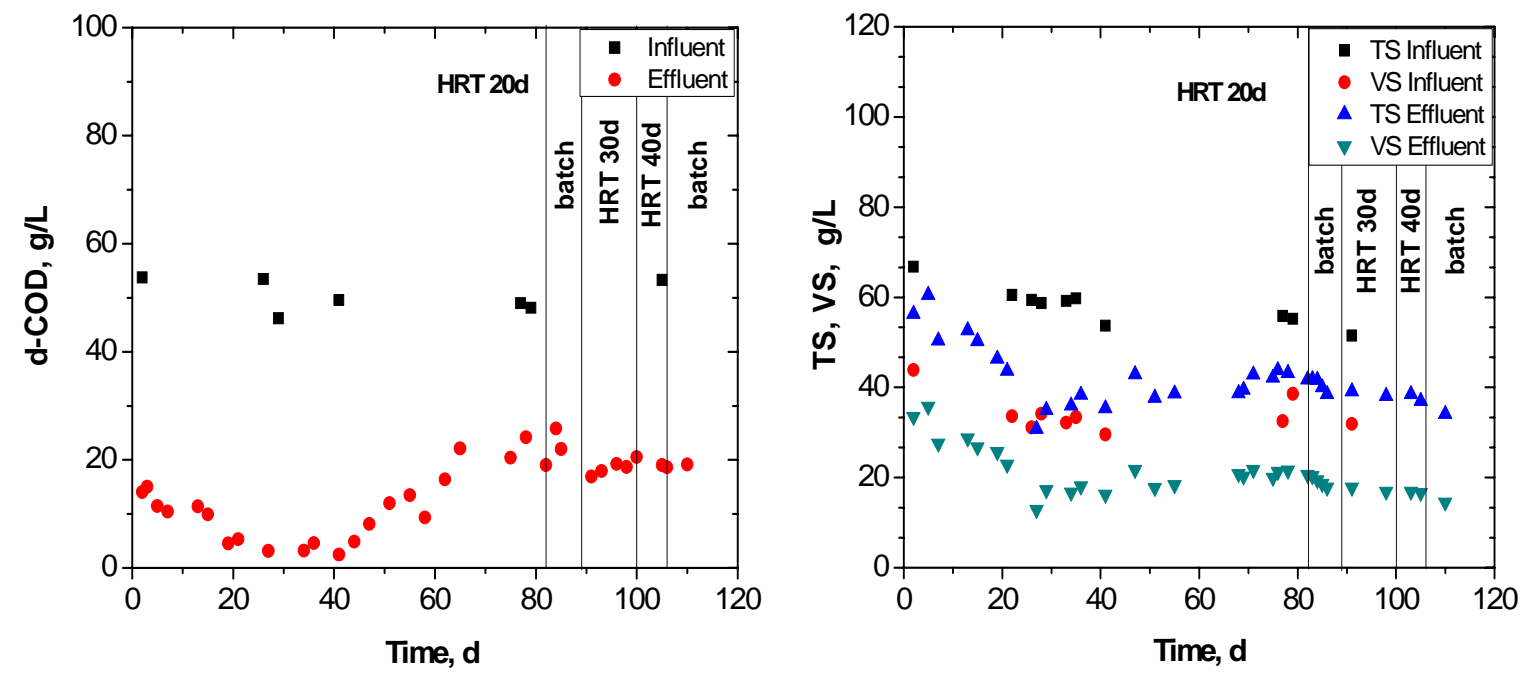

Figure 3. Influent and effluent concentrations of (a) dissolved COD, (b) Total Solids (TS) and Volatile Solids (VS) during the operation of the anaerobic reactor (single-stage process).

\subsection{Two-stage process}

\section{$\underline{\text { Acidogenic reactor }}$}

The average rate of biogas production in the acidogenic reactor was $0.11 \mathrm{~L} / \mathrm{Lreactor} /$ day with a composition of $\sim 90 \%$ in $\mathrm{CO}_{2}$ and $2-4 \%$ of $\mathrm{H}_{2}$ (Figure 4). A drastic decrease in the effluent $\mathrm{pH}$, comparing with the influent, was noticed in the reactor from 6.14 to 3.51 until the $69^{\text {th }}$ day of operation, which, in fact, was expected and can be attributed to VFAs production by the acidogenic bacteria. For example, acetic acid concentration increased from 1545 to 3930 $\mathrm{mg} / \mathrm{L}$ (mean influent and effluent values respectively). No dissolved COD removal was observed while the TS removal was $28.8 \%$, from 65.45 (influent) to $46.59 \mathrm{~g} / \mathrm{L}$ (effluent). The removal efficiency in VS concentration was $23.6 \%$ from 51.98 to $39.74 \mathrm{~g} / \mathrm{L}$ (see Figure 6 (a) and (b)).

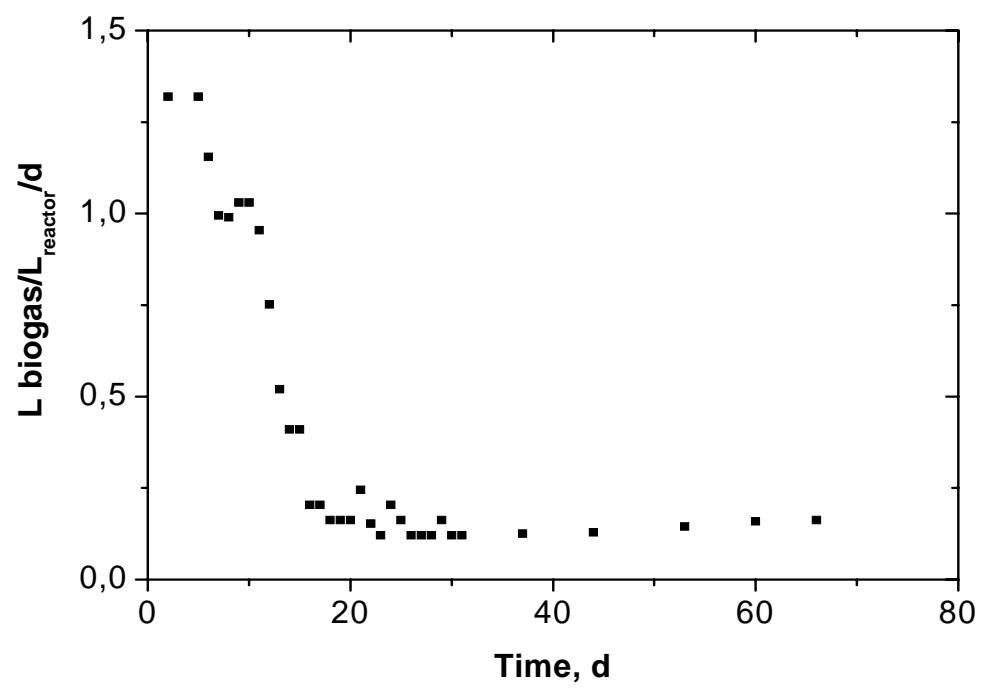

Figure 4. Biogas production in the acidogenic reactor. 

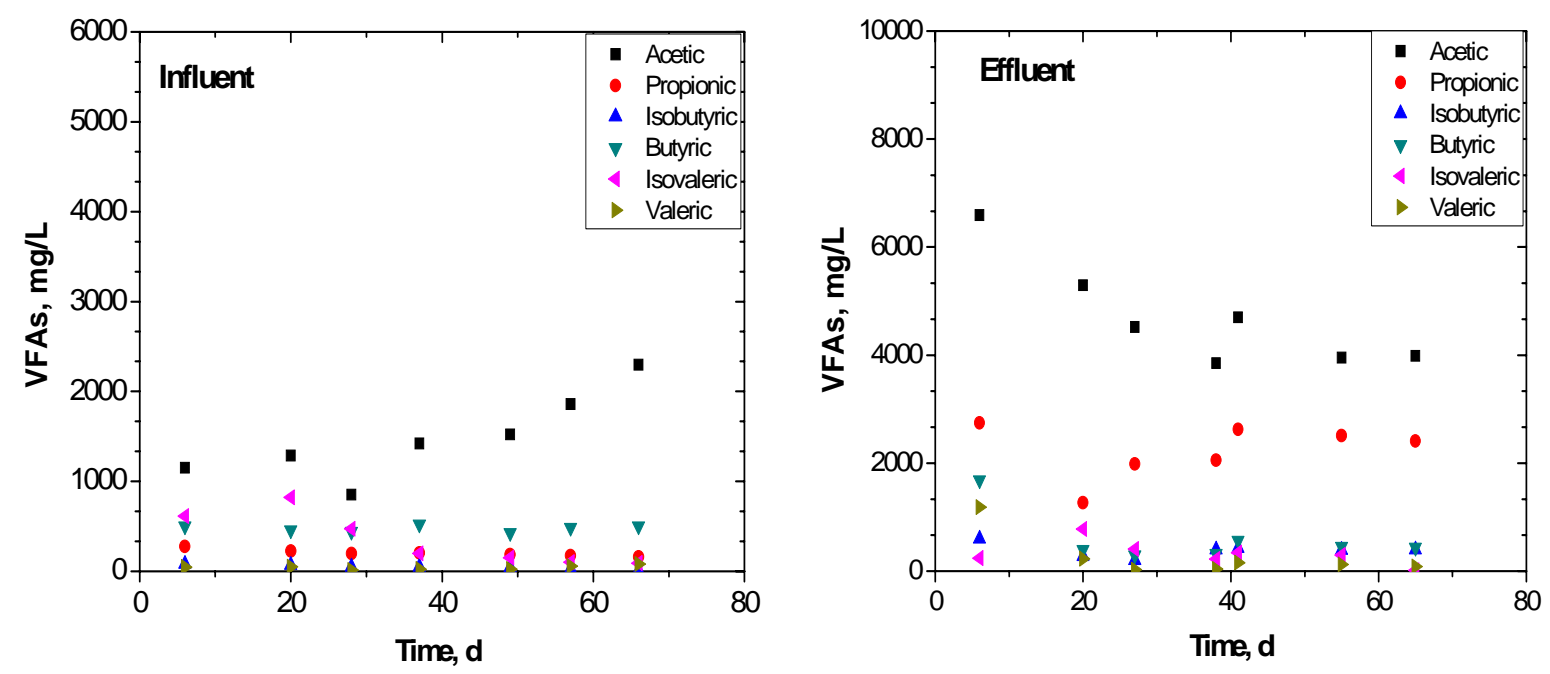

Figure 5. Concentration of Volatile Fatty Acids (VFAs) in (a) the influent and (b) the effluent of the acidogenic reactor (two-stage process).
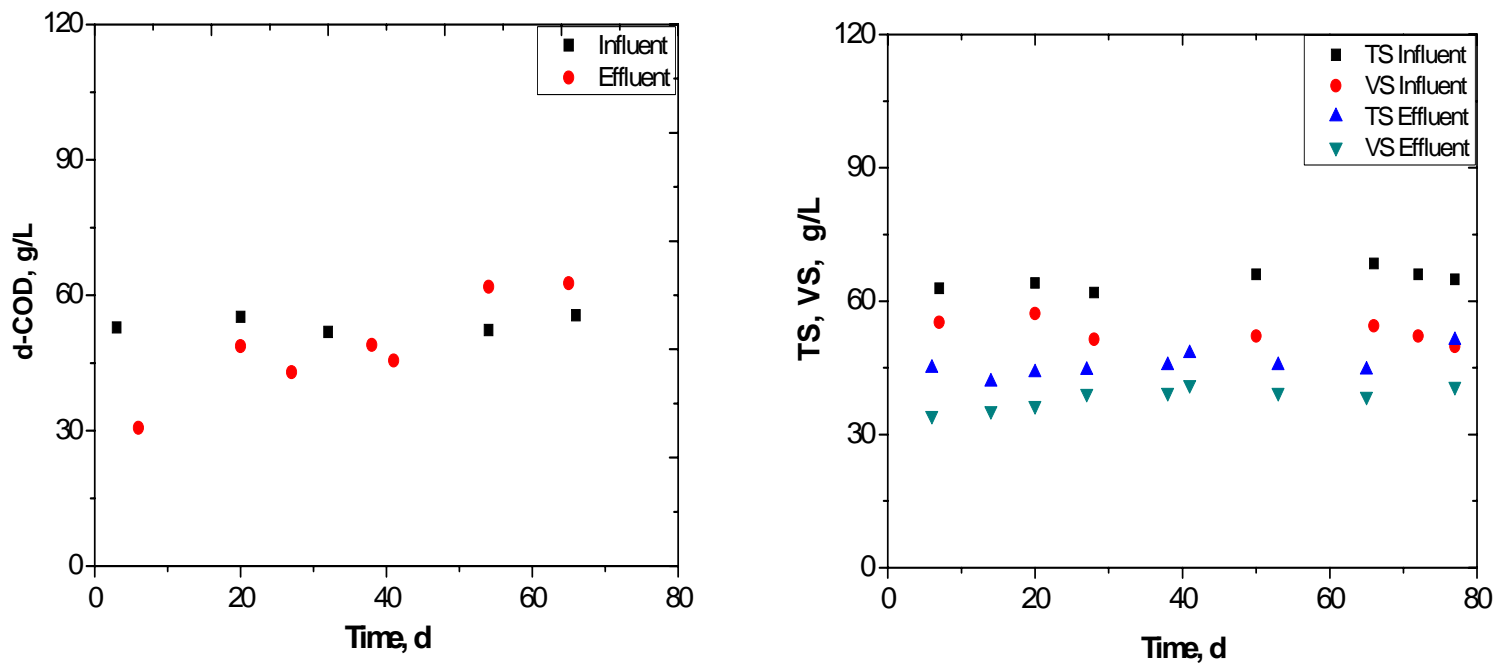

Figure 6. Influent and effluent concentrations of (a) dissolved COD, (b) Total Solids (TS) and Volatile Solids (VS) during the operation of the acidogenic reactor (two-stage process).

\section{$\underline{\text { Methanogenic reactor }}$}

A methane bioreactor was used for treating the acidified effluent of the first stage in order to assess the rate and extent of cheese whey biodegradation in such a two-stage system. As shown in Figure 7 (a) the biogas production rate presented a high increase and stabilized to $1.57 \mathrm{~L} / \mathrm{L}_{\text {reactor }} / \mathrm{d}$. The composition of biogas in methane fluctuated between 49 and $60 \%$. The methane production rate at the steady state reached up to $0.65 \mathrm{~L} \mathrm{CH}_{4} / \mathrm{L}_{\text {reactor }} / \mathrm{d}$. A gradual increase in effluent $\mathrm{pH}$ from 6.33 to 7.35 was observed during the whole experimentation period (Figure 7 (b)). This stability was achieved by adding $\mathrm{NaHCO}_{3}$ in the influent at a concentration of $14 \mathrm{~g} / \mathrm{L}$ of $\mathrm{NaHCO}_{3}$. The total bicarbonate alkalinity after the addition of $\mathrm{NaHCO}_{3}$ ranged to $4500 \mathrm{mg}$ of $\mathrm{CaCO}_{3} / \mathrm{L}$. 
The influent of the methanogenic digester was rich in VFAs, as anticipated due to the pretreatment in the acidogenic reactor. During the first 20 days of the experiment an accumulation of acetic and propionic acid was observed in the methanogenic reactor, which however remained stable for the rest of the experiment. The mean value of total VFAs concentration in the effluent was $7390 \mathrm{mg} / \mathrm{L}$ acetic acid and $4700 \mathrm{mg} / \mathrm{L}$ propionic acid, which didn't seem to inhibit the reactor's performance (see Figure 8 ).

The removal of total carbohydrates in glucose equivalents was $95.3 \%$ (data not shown) in the whole process (both reactors), since the concentration of carbohydrates in the influent was $32.1 \mathrm{~g} / \mathrm{L}$ and decreased to $1.5 \mathrm{~g} / \mathrm{L}$.

The dissolved COD removal during the examined scenario was $70.5 \%$ (mean value). The removal of COD in conjunction with the biogas production in the methanogenic reactor provided evidence of effective microbial activity from methanogenic bacteria. The TS removal efficiency remained constant, about $29.6 \%$ from 54.4 (influent) to $38.3 \mathrm{~g} / \mathrm{L}$ (effluent). On the other hand, the removal efficiency in VS concentration for the examined scenario was $56.7 \%$ from 40.54 to $17.55 \mathrm{~g} / \mathrm{L}$ (Figure 9 (a) and (b)).
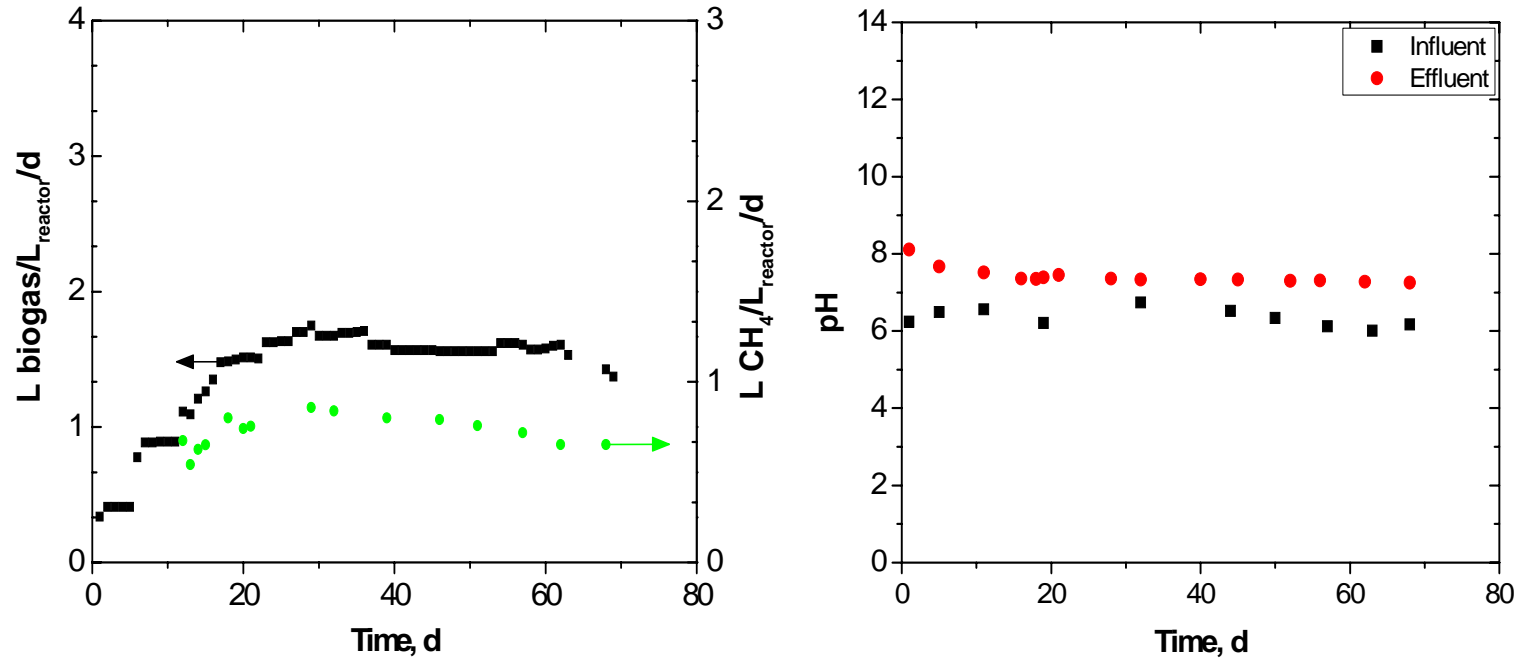

Figure 7. (a) Biogas and methane production and (b) Evolution of $p H$ during the operation of the methanogenic reactor (two-stage process). 


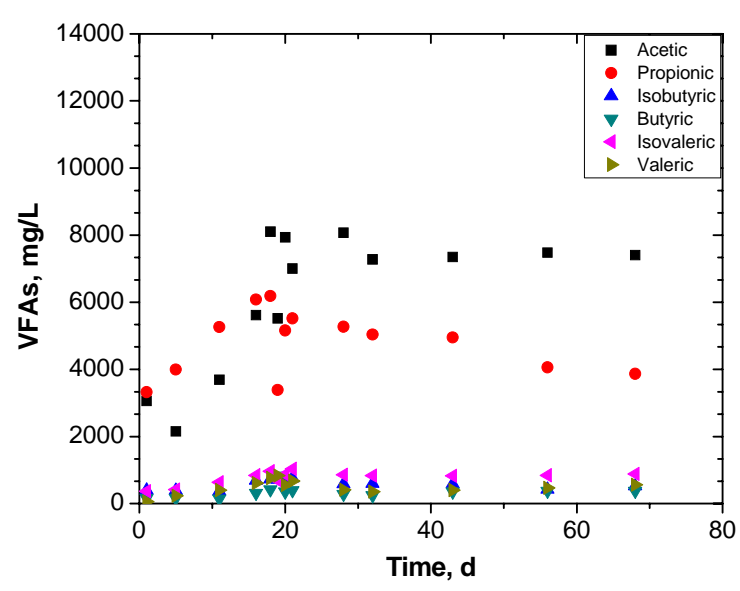

Figure 8. Concentration of Volatile Fatty Acids (VFAs) in the effluent of methanogenic reactor.
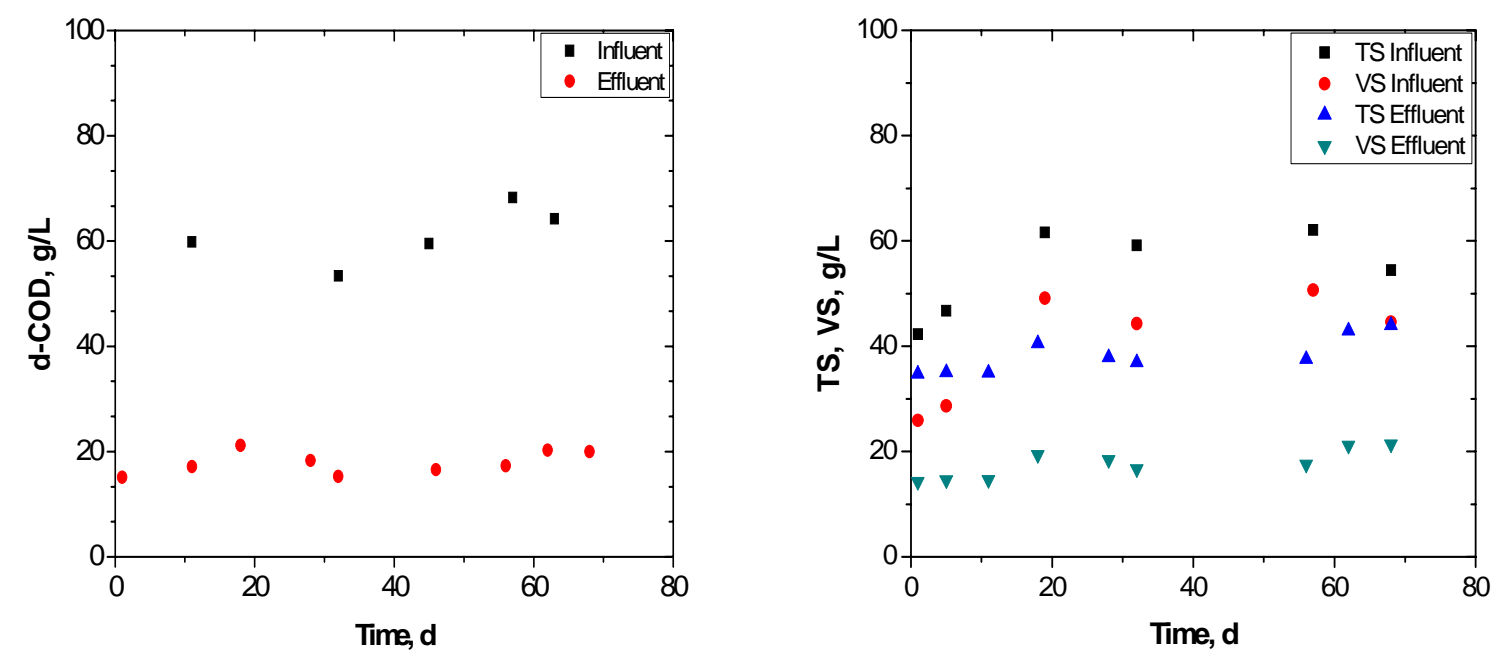

Figure 9. Influent and effluent concentrations of (a) dissolved COD, (b) Total Solids (TS) and Volatile Solids (VS) during the operation of the methanogenic reactor (two-stage process).

\section{CONCLUSIONS}

In this work, cheese whey anaerobic mesophilic biodegradation was comparatively studied in a single- and a two-stage anaerobic system using CSTR-type reactors operating at 20 and 23 days HRT respectively. The single-stage process presented many operational problems, as a result of little or no buffering capacity of whey, which caused the $\mathrm{pH}$ of the anaerobic digester to drop drastically and the process being inhibited by the high concentration of accumulated VFAs (both acetic and propionic). This type of inhibition proved to be irreversible and the digester was not able to recover even though it was operated batchwise and the value of the $\mathrm{pH}$ was restored to 7.0. On the contrary, the two-stage process exhibited a stable biogas production rate of $1.57 \mathrm{~L} / \mathrm{L}_{\text {reactor }} / \mathrm{d}$ with the mean composition of methane in the biogas reaching $54.3 \%$. The dissolved COD and total carbon concentration removal was $70.5 \%$ and $77.2 \%$ respectively.

Based on our results, cheese whey may be successfully treated by means of the anaerobic digestion process and the use of a two-stage anaerobic bioreactor system can be seen as a viable treatment option. An important consequence of the data from this study is that a two- 
phase set-up will be required to protect the methanogens in the methanogenic bioreactor from inhibitory low $\mathrm{pH}$ values and high VFA concentrations produced during the acidogenic phase. The two-stage system will allow pH control in the acidogenic phase should it be needed in a full-scale treatment plant.

\section{ACKNOWLEDGEMENTS}

The authors wish to thank the Community Initiative INTERREG IIIA Greece - Italy 20002006 for the financial support of this work under Grant No I3101004 (Acronym : AGROENERGY).

\section{REFERENCES}

[1] Gelegenis, J., Georgakakis, D., Angelidaki, I., Mavris, V., 2007. Optimization of biogas production by co-digesting whey with diluted poultry manure. Renewable Energy 32 (13), 2147-2160.

[2] Mawson, A.J., 1994. Bioconversion for whey utilization and waste abatement. Bioresource Technology 47 (3), 195-203.

[3] Mata-Alvarez, J., Macé, S., Llabrés, P., 2000. Anaerobic digestion of solid wastes. An overview of research achievements and perspectives. Bioresource Technology 74 (1), 3-16.

[4] Ke, S., Shi, Z., Fang, H.H.P., 2005. Applications of two-phase anaerobic degradation in industrial wastewater treatment. International Journal of Environment and Pollution 23 (1), 65-80.

[5] Antonopoulou,G., Stamatelatou,K., Venetsaneas,N., Kornaros,M., Lyberatos,G., 2008. Biohydrogen and methane production from cheese whey in a two-stage anaerobic process. Industrial and Engineering Chemistry Research 47 (15), 5227-5233

[6] Kalyuzhnyi, S.V., Perez Martinez, E., Rodriguez Martinez, J., 1997. Anaerobic treatment of high-strength cheese-whey wastewaters in laboratory and pilot UASBreactors. Bioresource Technology, 60 (1), 59-65.

[7] Gavala, H.N., Kopsinis, H.,Skiadas, I.V., Stamatelatou, K.,Lyberatos, G., 1999. Treatment of dairy wastewater using an upflow anaerobic sludge blanket reactor. Journal of Agricultural and Engineering Research 73 (1), 59-63

[8] Venetsaneas, N.,Antonopoulou, G.,Stamatelatou, K., Kornaros, M.,Lyberatos, G., 2009. Using cheese whey for hydrogen and methane generation in a two-stage continuous process with alternative $\mathrm{pH}$ controlling approaches. Bioresource Technology 100 (15), 3713-3717

[9] Yang, K., Yu, Y., Hwang, S.,2003. Selective optimization in thermophilic acidogenesis of cheese-whey wastewater to acetic and butyric acids: Partial acidification and methanation. Water Research 37 (10), 2467-2477

[10] Saddoud, A., Hassaïri, I.,Sayadi, S., 2007. Anaerobic membrane reactor with phase

separation for the treatment of cheese whey. Bioresource Technology 98 (11), 21022108.

[11] APHA, AWWA, WEF.,1995. Standard methods for the examination of water and wastewater. 19th ed. Washington DC, USA: American Public Health Association. 
Linnaeus ECO-TECH '10

Kalmar, Sweden, November 22-24, 2010

[12] Dareioti, M.A., Dokianakis, S.N., Stamatelatou, K., Zafiri, C.,Kornaros, M., 2009. Biogas production from anaerobic co-digestion of agroindustrial wastewaters under mesophilic conditions in a two-stage process. Desalination 248 (1-3), 891-906 